\title{
3rd Nobel Laureate Symposium on Global Sustainability: Transforming the World in an Era of Global Change
}

\author{
Carl Folke, Johan Rockström
}

Received: 17 August 2011/Accepted: 17 August 2011/Published online: 6 October 2011

In May 2011, Nobel Laureates and experts on sustainability gathered in Stockholm for the 3rd Nobel Laureate Symposium to discuss the necessity and opportunities in a world transition to global sustainability. This special section of Ambio is based on three working papers that provided the scientific foundation for the symposium dialogue.

The first paper Reconnecting to the Biosphere (Folke et al. 2011) calls for a shift in mind set, emphasizing that people shape the Earth System and are at the same time fundamentally dependent on the capacity of its biosphere to sustain our own development. Institutions and governance for building social-ecological resilience to deal with an interconnected and fluctuating global system becomes a central priority.

The second paper The Anthropocene: From global change to planetary stewardship (Steffen et al. 2011) focuses on the great acceleration into a human dominated geological epoch, the Anthropocene, and on identifying the Earth's safe operating space for societal development. The new era calls for planetary stewardship to fundamentally alter our relationship with the planet we inhabit.

The third paper Tipping towards sustainability: Emerging pathways of transformation (Westley et al. 2011) explores links between agency, institutions and socialecological innovation for navigating large-scale transformations towards global sustainability. What conditions are necessary to escape the current lock-in? Promising social and technical innovations creating planetary opportunities need to be connected to broad institutional resources and responses.

We have also included The Stockholm Memorandum: Tipping the scales towards sustainability, which was developed at the symposium. The memorandum was signed by the Nobel Laureates and handed over to the UN High-level Panel on Global Sustainability, active in preparing the Rio +20 UN Conference, 2012. The memorandum makes clear that sustainability is not about saving the environment. It is our future as part of the biosphere that is at stake. The challenge is broader than climate; it is about global change. Humanity must now become active stewards of the entire Earth system to safeguard the future.

The symposium provided a platform for science-policy dialogue, including a court case where Planet Earth put Humanity on trial with a court ruling by a Nobel Laureate Jury. The court case, talks and presentations are available at www.globalsymposium2011.org. The symposium also hosted a Nobel Laureate Choral Concert composed exclusively for this occasion and the Stockholm Dialogue on Global Sustainability-Seizing Planetary Opportunities, at The Royal Dramatic Theatre, with Nobel Laureates, scientists, policy makers, entrepreneurs and representatives from business, civil society and culture. The presence and engagement of HM King Carl XVI Gustaf and HRH Crown Princess Victoria are greatly acknowledged.

The 3rd Nobel Laureate Symposium was organized by the Royal Swedish Academy of Sciences, Stockholm Resilience Centre at Stockholm University, Stockholm Environment Institute, Beijer Institute of Ecological Economics and Potsdam Institute of Climate Impact Research.

We very much hope that you will be inspired reading this special section of Ambio.

\section{REFERENCES}

Folke, C., A. Jansson, J. Rockström, P. Olsson, S. Carpenter, A-S. Crepín, G. Daily, J., Ebbesson, et al. 2011. Reconnecting to the Biosphere. Ambio. doi:10.1007/s13280-011-0184-y

Steffen, W., Å. Persson, L. Deutsch, M. Williams, J. Zalasiewicz, C. Folke, J. Rockström, C. Crumley, et al. 2011. The Anthropocene: 
From global change to planetary stewardship. Ambio. doi: 10.1007/s13280-011-0185-x

Westley, F., P. Olsson, C. Folke, T. Homer-Dixon, H. Vredenburg, D. Loorback, J. Thompson, M. Nilsson, et al. 2011. Tipping towards sustainability: Emerging pathways of transformation. Ambio. doi:10.1007/s13280-011-0186-9

\section{AUTHOR BIOGRAPHIES}

Carl Folke $(\square)$ is Professor in natural resource management, Science Director of the Stockholm Resilience Centre at Stockholm University and Director of the Beijer Institute of Ecological Economics of the Royal Swedish Academy of Sciences. His research is on the role that living systems at different scales play in social and economic development and how to govern and manage for resilience in integrated social-ecological systems.
Address: Stockholm Resilience Centre, Stockholm University, Stockholm 10691, Sweden.

Address: The Beijer Institute of Ecological Economics, The Royal Swedish Academy of Sciences, P.O. Box 50005, Stockholm 10691, Sweden.

e-mail: carl.folke@beijer.kva.se

Johan Rockström is Professor in natural resource management and Executive Director of the Stockholm Resilience Centre at Stockholm University and of the Stockholm Environment Institute. He research is on agricultural water management, watershed hydrology, global water resources, eco-hydrology, resilience and global sustainability. Address: Stockholm Environment Institute and Stockholm Resilience Centre, Stockholm University, Stockholm 10691, Sweden. 